\title{
ATTRACTING OF FOREIGN INVESTMENTS FOR NATIONAL ECONOMY THROUGH THE EMISSION OF EUROBONDS
}

\author{
Konvisarova E.V., Levchenko T.A., Candidates of Economic Sciences \\ Dolgorukova V.I., Nesterenko M.S., Graduate students \\ Vladivostok State University of Economics and Service, Vladivostok, Russia \\ *E-mail: tat levchenko22@mail.ru
}

\begin{abstract}
Foreign investments are an important resource for the development of the Russian economy both at the macro level and at the branch level. This is especially important in the current political conditions, when anti-Russian sanctions actually deprived domestic financial and non-financial companies of the possibility of obtaining loans abroad on favorable terms. Moreover, there are unfavorable trends in foreign direct investment observed. All these options are stimulated the business community to find new, promising methods of attracting investments. One of them is using of Eurobonds. Eurobond loans are quickly gaining popularity, which determines the need to monitor the Eurobond market. In this scientific work was analyzed the volume and structure of Eurobond loans issued in Russia. Particular attention was paid to the issue of Eurobond loans by the largest Russian banking organizations and industrial companies. The conducted research made it possible to draw a conclusion about the importance of Eurobonds for the Russian loan market, to identify the directions of the positive and negative impact of Eurobond loans on the Russian economy and the activities of individual economic entities. The results of the research can be used to form investment strategies by financial and non-financial organizations.
\end{abstract}

\section{KEY WORDS}

Foreign investments, Eurobonds, capital, currency, bond issue, bond redemption.

Due to the tense political situation, many domestic companies lost the opportunity to obtain preferential loans from foreign banks. Thus, the era of cheap loans ended, and the Russian economy faced the question of how to raise funds for further development. Introduced in 2014, sanctions against major domestic banks reduced the amount of foreign currency on the Russian market, increased demand for it and became one of the reasons for the devaluation of the ruble.

In this situation, there was a need for alternative ways of attracting capital. This way was the issue of Eurobonds. The main objective of Eurobonds is to cover and restructure existing debts or replenish working capital. The main difference between Eurobonds and lending is deferred payment of the main debt. The issue of Eurobonds is important from the scientific point of view, as an element of microeconomics considering the structure of the borrowed capital of joint-stock companies. The study of this mechanism will determine the optimal ways to increase the profitability of enterprises.

Research of the mechanism of Eurobonding borrowed many domestic scientists. Representative of the State University Higher School of Economics Leonova N.V. [7] studied the system of registration of Eurobonds in domestic and international depositories. Ilyina A.I. and Zaitseva E.N. [1] representing South Ural State University, considered the importance of Eurobond loans for domestic metallurgical companies. Koren A.V. deals with the issues of the capital market at the Vladivostok State University of Economics and Service. [4]. In his article "Basic Directions for the Effective Management of the Investment Portfolio" he reviews debt instruments as part of portfolio investment.

However, not all issues in this area are sufficiently developed. Therefore, the purpose of this research is to analyze the mechanism of borrowing money by Russian companies through the issue of Eurobonds. 
Borrowing in the international capital market originated during the reign of Catherine II. In the Soviet period, the external debt tried to keep at the level of 5 billion US dollars, it was not more than 5\% of GNP [5]. Such a low indicator of external debt is due to the command economy, which did not recognize private property and, as a consequence, the absence of corporate loans. But after the death of L.I. Brezhnev's foreign debt has increased tenfold in seven years [2]. Thus, as an official receiver of the USSR, Russia has a significant debt burden of 123.5 billion US dollars for 1997. The borrower on the world capital market was Vneshekonombank of the USSR, it was through this structure that the issuance of debt securities was carried out. Remarkable is the fact that the Soviet papers actively bought American banks and funds.

In fact, Eurobonds are a tool for long-term borrowing of cash, by placing a bond in a foreign currency for the issuer and on a foreign exchange. Eurobonds have the following characteristics:

1. The nominal value (nominal). The price, which the issuer pays the bonds to the first investors. Often, the nominal value is 1,000 rubles.

2. Market price. The price determined on the exchange in the bidding process. It is defined as a percentage of the nominal, maybe as high (for example, 101.2\%) or below par $(98.7 \%)$.

3. Coupon. The value of the interest payment on the bond (measured in annual). The amount and date of coupon payment can be viewed at www.rusbonds.ru. Determined as a percentage of the nominal.

4. Redemption. Date, when the issuer pays to the investor the amount of the debt on the bond and the last interest payment. An analogue of the closing date of the deposit.

5. Rate to maturity. The rate in percent per annum, which the investor will receive if he holds the bond to maturity. It takes into account coupon income and income due to the difference in purchase and redemption prices.

6. Offer. The date when the issuer early (before redemption) will buy bonds from the investor at a price equal to par.

Eurobonds can be issued by the state and private organizations (corporate bonds). Issuers can issue Eurobonds of different levels of reliability. The main is the division into senior bonds and subordinated [9].

Senior bonds (senior bonds) are bonds with the priority right of claiming to the company's assets, secured by a legally fixed right to a specific part of the issuer's property. These bonds can be pledged to provide for any property [10].

Subordinated debentures represent unsecured debt obligations, in which the level of claims on assets is the lowest in comparison with all other classes of debt obligations. In case of liquidation of the company, the property claims of the holders of its subordinated bonds are satisfied only after the property claims of all "senior" creditors have been fully satisfied. Subordinated bonds of the new order are freely convertible into shares of the company [11].

Most often, Eurobonds are placed on the London Stock Exchange, since IOB section is considered to be one of the largest and most liquid in the world in terms of daily trading volume. Considering the fact that borrowing takes place on the international market, Euroclear and Clearstrream provide depositary and clearing services. In turn, at the state level, there is registration in banks - custodians. After the introduction of economic sanctions against Russia, brokers were obliged to change the custodian banks to the National Clearing Depository (NSD). The final nominal holder of the Eurobond is the investor [6].

The state more often uses Eurobond loans to cover the budget deficit and fulfill its obligations to citizens, not to implement large projects, also concerns the subjects of the federation. There are 13 issues in circulation now. Below are listed examples of sovereign Russian Eurobonds:

1. Russia -2017 , issue $12840059 \mathrm{~V}$. Bonds are traded on the London Stock Exchange with a yield of $3.25 \%$ per annum, semi-annual payments, denominated in US dollars. 
2. Russia - 2018, issue 49001RMFS. The bonds are traded on the London Stock Exchange with a yield of $7.85 \%$ per annum, semi-annual payments, but are mined in rubles. The total amount of the issue is 90 billion rubles.

3. Russia - 2018, Issue MK-0-CM-126. The bonds are traded on the Luxembourg Stock Exchange with a yield of $11 \%$ per annum, semi-annual payments, denominated in US dollars. The total amount of emission is $3,466,398,000$ US dollars.

Eurobond loans from the total amount of the state external debt amount to 37,042 million US dollars, compared to 50,864 million US dollars. The main reason lies in the fact that few credit institutions are able to provide the state with such a large amount of loans, without the use of syndicated loans. Therefore, Eurobonds remain the most effective way of attracting foreign funds.

Of the municipal Eurobonds in circulation on the German stock exchange are only Eurobonds of Moscow, which allows us to conclude that for the regions Eurobond loans are irrelevant. This is due to the lack of demand for bonds, and hence their liquidity [8].

Quite different is the situation with Eurobonds of Russian companies. All major commercial organizations place their Eurobonds on the London, Luxembourg and Frankfurt stock exchanges. These include not only banks with state participation, but also large industrial companies (Evraz, Nordgold, Alrosa, etc.).

Domestic companies have residents in circulation Eurobonds amounting to 485 billion US dollars. This is the main part of the gross external debt of the state. Comparing this indicator with the GDP of Russia for 2015, in the amount of 1.2 trillion US dollars, the debt burden is serious, but within the limits of the norm in comparison with other countries. For example, the ratio of the external debt of the United States to GDP is $98 \%$, Britain has $322 \%$, and Germany has $159 \%$ [3].

Evaluating the importance of Eurobond loans, it is necessary to consider the capital structure of the largest Russian companies from one industry. Preferably consideration of the banking sector, because this is the most financially active group of companies.

From the banking sector, it is advisable to compare the largest domestic bank - PJSC Sberbank, private bank PJSC Binbank and Alfa Bank. As of June 30, 2016, Sberbank issued debt securities worth 1.3 trillion from this mass of Eurobonds 603 billion rubles, with an average yield of $3.5-5 \%$ per annum. Thus, it can be concluded that almost half of Sberbank's debt securities are issued in the form of Eurobonds. Binbank issued Eurobonds for a total of 9 billion rubles, with a yield of $8.5 \%$ per annum, relative to the total amount of debt securities of 119 billion rubles. Alfa Bank issued Eurobonds worth 241 billion rubles, with a total amount of debt securities issued of 300 billion rubles. The rate on Alfa Bank's bonds averages about $7.5 \%$ per annum. Eurobond loans are actively used by Sberbank and Alfa Bank. Eurobonds of Sberbank are in demand, therefore their rate is lower than that of Binbank and Alfa Bank. Binbank makes attempts to enter the international Eurobond market, but this method of borrowing is not profitable for it. Foreign investors, relying on the level of reliability of Binbank, as an issuer, require a greater return on investment.

Eurobonds can be issued not only by financial institutions, but also by companies from the real sector of the economy. It is advisable to consider the company Gazprom, since it is a large domestic company with state participation in the authorized capital, and the company Norilsk Nickel as a large private industrial company. Gazprom has 23 issues of Eurobonds nominated in USD, CHF and EUR. The volume of loans in excess of 1.4 trillion rubles and the average rate at $6.5 \%$ per annum. The company MMC Norilsk Nickel issued 3 issues of Eurobonds nominated in USD. The total volume of Eurobonds is 181 billion rubles, and average yield of about $5 \%$ per annum. Thus, it can be concluded that companies from the real sector of the economy are actively attracting loans through the issue of Eurobonds. At the same time, the availability of quality assets in the company's ownership increases their reliability rating and reduces the yield on the securities issued by them.

Thus, the analysis of the Russian market of Eurobond loans showed a well-established mechanism of foreign borrowing. In the structure of the overall external debt of the Russian Federation, Eurobond loans occupy a significant part. Attraction of foreign capital is mutually beneficial for domestic companies and the state, since it allows you to receive foreign 
currency at low interest rates, and for foreign investors - to receive a percentage that exceeds the yield of their securities. This allowed increasing the number of carry treading operations used by foreign hedge funds. Analyzing the structure of debt obligations of domestic companies, we can conclude that due to the specifics of business, it is advantageous for companies to attract borrowed funds through the issue of Eurobonds. This mechanism is most successfully used by the financial sector of the economy. Russian banks actively switched to issuing Eurobonds after they blocked access to loans from foreign banks.

However, Eurobond loans also have a negative impact on the Russian economy. Since the funds are attracted in foreign currency, the conversion of funds affects the exchange rates. In this way, attracting funds through Eurobonds can adversely affect domestic companies due to the increasing volatility of foreign exchange rates. To the greater extent, exporters suffer from this, the inflow of foreign currency increases the demand for the ruble and in case of currency revaluation of the received income, the company has losses. This is a big problem for many small companies that are not able to hedge this type of risk.

\section{REFERENCES}

1. Ilina A.I., Zaitseva E.N. Eurobonds as one of the most stable financial instruments of the Russian stock market. Modern trends in economics and management: a new view. 2011. №11-1. pp. 82-86.

2. Ilina A.I., Zaitseva E.N. Eurobonds as an effective way of attracting investment resources to the regions (by the example of metallurgical companies in the Chelyabinsk region). Strategies for sustainable development of Russian regions. 2011. №6. pp. 70-73.

3. Konvisarova $\mathrm{E}$. The nature and problems of tax administration in the Russian Federation. Mediterranean Journal of Social Sciences. №5. pp. 78-83.

4. Koren A.V. The main directions of effective investment portfolio management. International Journal of Applied and Fundamental Research. 2015. №10-4. pp. 704-706.

5. Koren A.V., Goloyad A.N. Analysis of new investment opportunities based on the use of an individual investment account. International Journal of Applied and Fundamental Research. 2016. №12-9. pp. 1696-1699.

6. Kudryavtseva O.P. Russia in the Eurobond market. Economic development of society in modern crisis conditions. 2016. №3. pp. 231-233.

7. Leonova N.V. Designing a repository to record transactions with euro-bonds of residents of the Russian Federation. Aktalnye voprosy sovr. nauki. 2009. №7-1. pp. 117-123.

8. Luzan A.A. On the factors affecting the emission of Russian Eurobonds. $V$ mire nauki $i$ innovatsii. 2016. pp. 105-107.

9. Poltava T.V., Ignatieva E.V. Eurobonds as an instrument of the international capital market. Molodoi uchenyi. 2014. №20. pp. 379 -382.

10. Shikhshabekova H.M. Eurobonds of Russian issuers. Economika i sotsium. 2014. №24(11). Pp. 1239-1242.

11. Tropina Z.N. Eurobonds, features of issue. Socio-economic and economic problems of the development of the Russian Federation. Moscow, 2013. pp. 59-63. 